American Journal of Applied Sciences 7 (9): 1231-1236, 2010

ISSN 1546-9239

(C) 2010 Science Publications

\title{
Heavy Metals Contamination of Road-Deposited Sediments
}

\author{
Jonathan Yisa \\ Department of Chemistry, Federal University of Technology, \\ PMB 65, Minna, Nigeria
}

\begin{abstract}
Problem statement: Impact of anthropogenic activities on man and his environment as a result of the growing rate of urbanization in Bida, Nigeria is of a great concern. Street sediments that accumulate along pavements in urban environments have the potential to provide considerable loadings of heavy metals to receiving waters and water bodies, particularly with changing environmental conditions. The objective of this research was to evaluate the streets sediment contamination in Bida, Nigeria. Approach: Fifty five sediment samples were collected from four roads that experience intense traffic conditions and analyzed in the laboratory for some heavy metals by atomic absorption Spectrophotometric method and multivariate statistical techniques. Results: The overall decreasing metal concentration order was: $\mathrm{Pb}>\mathrm{Mn}>\mathrm{Fe}>\mathrm{Zn}>\mathrm{Cu}>\mathrm{Cr}>\mathrm{Ni}>\mathrm{Cd}$. Significantly positive correlation was only found between $\mathrm{Cd}$ and organic matter $(\mathrm{r}=0.580)$. Factor analysis shows that road deposited sediment quality data consists of four major components accounting for $77.11 \%$ of cumulative variance of the contamination: $\mathrm{Ni}, \mathrm{pH}$ and silt + clay; $\mathrm{Cr}, \mathrm{Fe}$ and organic matter; $\mathrm{Mn}$ and $\mathrm{Zn}$ and finally $\mathrm{Cu}$ and $\mathrm{Pb}$. Discriminant analysis revealed that the first two Discriminate Functions (DF1 and DF2) contain $90.61 \%$ information for $\mathrm{Cu}, \mathrm{Pb}$ and $\mathrm{Ni}$ accumulation. Conclusion: This study concluded that the concentrations of all metals measured in Bida can be considered to present a low level of contamination and that multivariate statistical analysis is a useful tool in understanding contaminants relationships.
\end{abstract}

Key words: Anthropogenic, environment, multivariate, discriminant analysis, heavy metals

\section{INTRODUCTION}

The presence of Metal pollutants in road-deposited sediments plays an important role in dictating urban storm water quality. Cities and Towns under various geographical, geological, climatic and sociological conditions are usually considered as big sources of pollutants irrespective of specific types of men activities (Mielke, 1994; Tiller, 1989). Established research has shown that sediments and dusts transported and stored in the urban environment have the potential to provide considerable loadings of heavy metals to receiving waters and water bodies, particularly with changing environmental conditions (Pereira et al., 2007).

Street sediments that accumulate along pavements in urban environments originate mainly from natural and anthropogenic sources. Heavy metals from natural sources vary significantly within catchments and may include materials transported by water from surrounding soils, pollutants from dry and wet atmospheric deposition and biological materials from vegetation. Significant quantities of particulate matter can also be attributed to anthropogenic sources such as industrial processes, abrasion of vehicular components and their exhaust emissions, incinerators, power plants and foundry operations, tyre and road surface wear (Sutherland and Tolosa, 2000; Pagotto et al., 2001).

These deposits as street sediment have become an important medium for the study of anthropogenic pollutants and their possible sources (Ferguson and Kim, 1991; Watts and Smith, 1994; De Miquel et al., 1997; Naqerotte and Day, 1998; McAllister et al., 2000; 2005). Urban street sediments have limited residence times and therefore provide a record of recent accumulations (Pereira et al., 2007; Pagotto et al., 2001; Sutherland and Tolosa, 2000; Sutherland, 2003). The aim of this study was to examine the extent of heavy metal contaminations in Bida road-deposited sediments. The use of statistical analysis as a useful tool for better understanding of the relationships among the studied parameters was also discussed.

\section{MATERIALS AND METHODS}

Studied area: Bida town lies at $9^{\circ} 06^{\prime} \mathrm{N}$ and $6^{\circ} 01^{\prime} \mathrm{E}$ on the Nupe sandstone formation which consists of plains with ironstone capped hills or mesas. The scenery is 
fairly uniform since lithology and rock structure are not the existence of large areas of fadama. The northern edge of the town consists of a broken off plateau. From the foot of two flat-topped hills the town sweeps down into the plain. The town is drained by the Chicen and Mussa streams with the third stream Landzu, which flows right across the heart of the town. Bida is in the low basin that is formed by the valleys of the two rivers, Niger and Kaduna (Mahvi et al., 2005).

Sediments sampling: Fifty five sediment samples were collected from four roads that experience intense traffic conditions in Bida Town with the aid of stainless spoon, washed with soap and rinsed with distilled water after each sampling (Awofolu, 2005). These roads are BCCIdi road, Govt. College-Post Office road, Banwuya road and Mokola road. Three sampling sites were designated on each road except Mokola road that had two sites.

The samples were collected once every month for five months during the rainy season from May to September 2009. All the samplings were performed three days after the rain. Samples collected were stored in sealed polythene bags and transported to the laboratory for pre-treatment and analyses.

Laboratory analysis: The soil samples were air-dried, mechanically ground using a stainless steel roller and sieved to obtain $<2 \mathrm{~mm}$ fraction. A $20-30 \mathrm{~g}$ sub sample was drawn from the bulk soil ( $<2 \mathrm{~mm}$ fraction) and reground to obtain $<200 \mu \mathrm{m}$ fraction using a mortar and pestle. This fine material was used to determine organic carbon and total metal content in soil. The $<2 \mathrm{~mm}$ fraction was used to determine $\mathrm{pH}$ (1: 5 soil water extract and particle size analysis using methods outlined by Rayment and Higginson (1992). Organic carbon was determined by the modified Walkley and Black method by Damian and Damian (2007).

Soil samples were digested in a mixture of concentrated nitric acid $\left(\mathrm{HNO}_{3}\right)$, concentrated Hydrochloric acid $(\mathrm{HCl})$ and $27.5 \%$ hydrogen peroxide $\left(\mathrm{H}_{2} \mathrm{O}_{2}\right)$ according to the USEPA Method 3050B for the analysis of heavy metals (USEPA, 1996). A reagent blank was run for each set of six samples.

The extracts were analyzed by atomic absorption spectrophotometer (Perkin Elmer, Model No. 2380).

Statistical analysis: In order to quantitatively analyze and confirm the relationship among soil properties $(\mathrm{pH}$, $\mathrm{OM}$ and silt + clay) and heavy metal content, a Pearson's correlation analysis was applied to dataset.

Principal Component Analysis (PCA) was adopted to assist the interpretation of elemental data. This powerful method allows identifying the different groups of metals greatly variable. An important feature of the scenery is that correlate and thus can be considered as having a similar behavior and common origin (Tahri et al., 2005). It should be noted that parametric statistical tests require the data to be normally distributed. Therefore, it was checked if the data came from a population with normal distribution by applying Shapiro-Wilk's test (significance level, $\alpha=0.05$ ). The non-normal data were transferred logarithmically to ensure normal distribution.

All the statistical analysis were performed using SPSS for Windows (release Ver.11, Inc., Chicago, IL).

\section{RESULTS AND DISCUSSION}

A close look at the Table 1 shows that high mean metal concentrations were found for all the metals except $\mathrm{Cd}$. Average $\mathrm{Pb}$ concentration was $59.67 \mathrm{mg}$ $\mathrm{dm}^{-3}$ followed by $\mathrm{Mn}, \mathrm{Fe}, \mathrm{Zn}, \mathrm{Cu}, \mathrm{Cr}$ and $\mathrm{Cd}$ at 17.18 , $15.66,13.89,11.67,8.57$ and $1.69 \mathrm{mg} \mathrm{dm}^{-3}$ respectively. The variability in range of all the metal distributions as compared with their means respectively is an indication of a pollution of the sediment with that metal ion. The decreasing trend of average metal levels was as follows:

$$
\mathrm{Pb}>\mathrm{Mn}>\mathrm{Fe}>\mathrm{Zn}>\mathrm{Cu}>\mathrm{Cr}>\mathrm{Ni}>\mathrm{Cd}
$$

The mean and median were used as estimates of central tendency. Standard errors of the mean were all small. The distribution of original data for $\mathrm{Ni}, \mathrm{Fe}, \mathrm{Mn}$, $\mathrm{Zn}, \mathrm{Cu}$ and $\mathrm{Cd}$ are positively skewed while $\mathrm{Cr}$ and $\mathrm{Pb}$ were negatively skewed. Despite this skewness, the mean and median values are quite similar for $\mathrm{Fe}$ and $\mathrm{Cd}$ with medians having smaller values than means. This indicates that measures of central tendency are not dominated by outliers in the distribution. The effect of extreme outliers is greater for the distribution of $\mathrm{Cr}, \mathrm{Ni}$, $\mathrm{Mn}, \mathrm{Zn}$ and $\mathrm{Cu}$ values. In each case, test for normality were conducted using the test based on analysis of the combined effects of skewness and kurtosis. The substantial difference in the symmetric parameters in the case of $\mathrm{Zn}, \mathrm{Cu}$ and $\mathrm{Cd}$ indicated a non-normal distribution, thus supporting a possibility of random infiltration of the metals from some anthropogenic sources. Large standard deviations in the case of $\mathrm{Pb}$, $\mathrm{Cu}, \mathrm{Mn}$ and $\mathrm{Zn}$ levels revealed their randomly fluctuating concentration levels in the sediment.

Among significant variables that controls or influences the distribution and concentrations of heavy metals in the environment are the grain size of sediments and organic matterv (Lin et al., 2002; Huang and Lin, 2003; Lakhan et al., 2003). The degree of correlation between trace metals and organic matter and size distribution is often used to study the origin of many metal (Jumbe and Nandini, 2009). To verify this 
relationship in this study, correlations between all the metals and the parameters mentioned were carried out.

Correlation coefficients for the metals silt plus clay and organic matter were low except the correlation between organic matter and $\mathrm{Cd}$ (Table 2). One reason for this occurrence could be the fact that the analyzed grain sizes were not in the silt plus clay fraction. This result was unexpected, since heavy metals have a high affinity for organic and silt and clay fractions (MihalyCozmuta et al., 2005; Zonta et al., 1994). This low correlation can be indicative of distinctive sources for these metals in these urban areas. Pereira et al. (2007) discovered that the particle size distribution for urban street sediments does not obey the laws of the hydrodynamics like materials found in natural environments such as beaches and rivers. For example, in urban environment particulate matter can be deposited in different ways and these include moving parts of vehicles, loads spilling from trucks, accidents, erosion of gardens and atmospheric deposition. They also noted that urban runoff travels down gradients in accordance with the urban landscape, specifically topography and slope gradients. The fine sediments are swept and flushed along its path, whereby the runoff eventually becomes highly enriched with heavy metals.

In contrary to Pereira et al. (2007) observations, some researchers (Ujevic et al., 2000; Zhang et al., 2001; Che et al., 2003; Avila-Perez et al., 1999) found organic matter to be associated with the highest concentrations of heavy metals.

In addition to correlation analysis, Factor Analysis (FA) of the studied road deposited sediment samples was performed in order to get an overall impression about assembling the samples in a multidimensional space defined by the chosen metals. The FA has emerged as a useful tool for better understanding of the relationships among the variables (e.g., metal concentrations in the present study) and for revealing groups (or clusters) that are mutually correlated within a data body. This procedure reduces overall dimensionality of the linearly correlated data by using a smaller number of new independent variables, called Varifactor (VF), each of which is a linear combination of originally correlated variables. The rotated Principal Component Loadings (Factors) are given in Table 3.

Four Factor Components (Eigen values>1) emerged accounting for $77.11 \%$ of cumulative variance. The first Factor loading with $25.93 \%$ variance showed higher loadings for $\mathrm{Ni}$ and silt + Clay and moderate loading for $\mathrm{pH}$. The sediment physico-chemical properties such as $\mathrm{pH}$ and clay content could have contributed to $\mathrm{Ni}$ retention in the sediment, resulting in low mobility of the metal (Ong and Kamaruzzaman, 2009). Odero et al. (2000) found that high $\mathrm{pH}$ could result in precipitation of metals, however clay adsorbed heavy metals.

Factor loading with $21.80 \%$ of total variance, had higher loadings for $\mathrm{Cr}$ and $\mathrm{Fe}$, along with significant contributions from organic matter. These could be conceived to mainly originate from domestic waste discharged in some of the areas and decomposition of vehicle and machine scraps apart from their natural occurrence. The third Factor had higher loadings for Mn and $\mathrm{Zn}$ at $17.32 \%$ of total variance, while the fourth Factor loading at $15.13 \%$ of total variance showed higher loadings for $\mathrm{Cu}$ and moderate loading for $\mathrm{Pb}$. These might be due to soldering and battery charging activities going on in this area. $\mathrm{Pb}$ and $\mathrm{Cu}$ are integral components of the raw materials used in soldering wires and $\mathrm{Pb}$ accumulators (Odero et al., 2000). Also automobiles and paints are very important sources of $\mathrm{Pb}$ contamination in urban environments (Baptista Neto et al., 2000).

Table 1: Basic statistical parameters for the distribution of selected metals $\left(\mathrm{mg} \mathrm{dm}^{-3}\right)$ in road sediment samples from Bida

\begin{tabular}{|c|c|c|c|c|c|c|c|c|}
\hline & Min & Max & Mean & Median & SD & SE & Skewness & Kurtosis \\
\hline $\mathrm{Cr}$ & 3.00 & 12.00 & 8.57 & 9.00 & 2.34 & 0.59 & -0.74 & 0.63 \\
\hline $\mathrm{Ni}$ & 1.00 & 18.00 & 7.89 & 8.00 & 4.26 & 1.06 & 0.31 & 1.21 \\
\hline $\mathrm{Fe}$ & 9.20 & 26.70 & 15.66 & 15.35 & 4.19 & 1.05 & 1.04 & 1.97 \\
\hline Mn & 1.20 & 80.00 & 17.18 & 7.15 & 21.92 & 5.48 & 1.91 & 3.70 \\
\hline $\mathrm{Zn}$ & 3.40 & 70.00 & 13.89 & 9.60 & 15.60 & 3.90 & 3.48 & 13.00 \\
\hline $\mathrm{Cu}$ & 3.33 & 97.00 & 11.67 & 6.24 & 22.83 & 5.71 & 3.96 & 15.76 \\
\hline $\mathrm{Pb}$ & 7.22 & 88.80 & 59.67 & 78.15 & 35.17 & 8.79 & -0.79 & -1.43 \\
\hline $\mathrm{Cd}$ & 1.33 & 3.44 & 1.69 & 1.42 & 0.67 & 0.17 & 2.40 & 4.55 \\
\hline
\end{tabular}

Table 2: Pearson correlation coefficient matrix for heavy metals in Bida Town streets sediments

\begin{tabular}{|c|c|c|c|c|c|c|c|c|c|c|}
\hline & $\mathrm{Cr}$ & $\mathrm{Ni}$ & $\mathrm{Mn}$ & $\mathrm{Zn}$ & $\mathrm{Cu}$ & $\mathrm{Pb}$ & $\mathrm{Cd}$ & $\mathrm{pH}$ & Organic matter & Silt + clay \\
\hline $\mathrm{Cr}$ & 1.000 & & & & & & & & & \\
\hline $\mathrm{Ni}$ & 0.214 & 1.000 & & & & & & & & \\
\hline $\mathrm{Mn}$ & 0.033 & -0.214 & 1.000 & & & & & & & \\
\hline $\mathrm{Zn}$ & -0.239 & -0.277 & 0.476 & 1.000 & & & & & & \\
\hline $\mathrm{Cu}$ & 0.288 & 0.182 & -0.211 & -0.080 & 1.000 & & & & & \\
\hline $\mathrm{Pb}$ & 0.138 & -0.120 & -0.034 & 0.280 & 0.189 & 1.000 & & & & \\
\hline $\mathrm{Cd}$ & 0.106 & 0.265 & -0.234 & -0.159 & -0.104 & 0.228 & 1.000 & & & \\
\hline $\mathrm{pH}$ & 0.138 & -0.269 & -0.351 & -0.276 & 0.346 & 0.270 & -0.360 & 1.000 & & \\
\hline Organic matter & 0.357 & 0.136 & 0.222 & -0.010 & -0.126 & -0.013 & $0.502 *$ & -0.228 & 1.000 & \\
\hline Silt + clay & 0.320 & -0.448 & 0.201 & -0.059 & -0.094 & 0.330 & -0.332 & $0.580 *$ & 0.049 & 1.000 \\
\hline
\end{tabular}


Discriminant analysis was also used to investigate whether the variations of the various metals along the road sediments had statistical significant concentrations. The discriminant analysis results for each of the six metals are summarized in Table 4.

For discrimination of the samples according to the sampling sites, the LDA yielded a $100 \%$ classification success when using all 10 originally available variables as revealed in Table 4. Since they are hierarchical, the first two Discriminant Functions (DF1 and DF2) contain almost $90.61 \%$ of total information and are well representing the sample categorization.

The statistical analysis of Table 4 shows that $\mathrm{Cu}$ and $\mathrm{Pb}$ are most important for DF1 while $\mathrm{Ni}$ as could be seen is very important for DF2. DF3 had Cd and Silt + Clay and DF4 is Ni and Silt+Clay. Nickel, Fe, Pb, Cd and Silt + Clay are the most important for DF5. The variable that is most important for DF6 are $\mathrm{Ni}, \mathrm{Fe}, \mathrm{Cu}$, $\mathrm{Pb}, \mathrm{pH}$ and Silt + Clay. $\mathrm{Ni}, \mathrm{Fe}$ and $\mathrm{Cd}$ were found to be most important to DF7, however, the impact on the discrimination of road sediments (DF2-DF7) in Bida is pretty low (less than $10 \%$ altogether) since it is given by a combination of factors: Relative percentage valid for the given DF (e.g., $5.43 \%$ for DF2) and the value of the Standardized Discriminant Function Coefficient (SDFC).

Table 5 shows that the concentrations of all metals measured in Bida can be considered to present a low level of contamination and pose no serious threat to the ecosystems when compared to some location around the world.

Table 3: Varimax normalized rotated principal component loadings of selected metals and sediment properties

\begin{tabular}{|c|c|c|c|c|}
\hline & \multicolumn{4}{|l|}{ Factors } \\
\hline & VF1 & VF2 & VF3 & VF4 \\
\hline $\mathrm{Cr}$ & 0.190 & 0.810 & -0.114 & 0.246 \\
\hline $\mathrm{Ni}$ & 0.726 & 0.454 & -0.281 & 0.148 \\
\hline $\mathrm{Fe}$ & -0.497 & 0.743 & -0.209 & 0.179 \\
\hline $\mathrm{Mn}$ & 0.135 & 0.189 & 0.773 & -0.235 \\
\hline $\mathrm{Zn}$ & -0.056 & -0.259 & 0.859 & 0.213 \\
\hline $\mathrm{Cu}$ & -0.127 & 0.088 & -0.234 & 0.772 \\
\hline $\mathrm{Pb}$ & 0.306 & 0.032 & 0.296 & 0.697 \\
\hline $\mathrm{pH}$ & 0.677 & -0.108 & -0.481 & 0.402 \\
\hline Organic matter & 0.010 & 0.694 & 0.252 & -0.255 \\
\hline Silt + clay & 0.885 & 0.264 & 0.019 & 0.074 \\
\hline Eigenvalue & 2.593 & 2.180 & 1.732 & 1.206 \\
\hline Total variance $(\%)$ & 25.930 & 21.800 & 17.320 & 12.060 \\
\hline Cumulative (\%) & 25.930 & 47.730 & 65.050 & 77.090 \\
\hline
\end{tabular}

Table 4: Standardized discriminate function coefficients

\begin{tabular}{|c|c|c|c|c|c|c|c|}
\hline & DF1 $(65.31 \%)$ & DF2 $(90.61 \%)$ & DF3 $(96.04 \%)$ & DF4 $(98.07 \%)$ & DF5 $(99.40 \%)$ & DF6 (99.97\%) & DF7 $(100 \%)$ \\
\hline $\mathrm{Cr}$ & -0.67 & 0.15 & 0.03 & 0.15 & 0.42 & 0.88 & 0.13 \\
\hline $\mathrm{Ni}$ & -0.42 & 1.06 & -0.16 & 1.23 & 2.21 & 2.42 & 1.04 \\
\hline $\mathrm{Fe}$ & 0.93 & -0.47 & 0.11 & -0.96 & -2.63 & -2.71 & -1.20 \\
\hline $\mathrm{Mn}$ & 0.03 & -0.46 & -0.30 & -0.08 & -0.10 & -0.96 & 0.54 \\
\hline $\mathrm{Zn}$ & 0.66 & -0.05 & 0.57 & 0.43 & 0.56 & 0.79 & 0.46 \\
\hline $\mathrm{Cu}$ & 1.29 & -0.19 & -0.14 & 0.12 & 0.79 & 1.48 & 0.72 \\
\hline $\mathrm{Pb}$ & 1.03 & -0.10 & -0.76 & -0.22 & -1.49 & -1.36 & -0.45 \\
\hline $\mathrm{Cd}$ & 0.59 & 0.41 & 1.07 & -0.22 & 1.38 & 0.97 & 1.20 \\
\hline $\mathrm{pH}$ & -0.57 & 0.11 & -0.17 & -0.85 & -0.86 & -1.65 & 0.31 \\
\hline Organic matter & -0.21 & 0.31 & -0.43 & 0.45 & -0.82 & -0.56 & -0.11 \\
\hline Silt + clay & 0.38 & 0.15 & 1.02 & 1.01 & 1.74 & 2.95 & 0.75 \\
\hline
\end{tabular}

Note: The variables most important for discriminating classes are marked by bold faces

Table 5: Comparison of sediment in this Study and other documented sediment levels $\left(\mathrm{mg} \mathrm{kg}^{-1}\right)$ around the world

\begin{tabular}{|c|c|c|c|c|c|c|c|c|}
\hline Location Panama & $\mathrm{Mn}$ & $\mathrm{Zn}$ & $\mathrm{Cu}$ & $\mathrm{Pb}$ & $\mathrm{Ni}$ & $\mathrm{Cr}$ & $\mathrm{Fe}$ & $\mathrm{Cd}$ \\
\hline Punta Mala Bay ${ }^{\mathrm{a}}$ & 295 & 105.00 & 56.30 & 78.20 & 27.3 & 23.30 & 9827 & $<10.00$ \\
\hline Toro Point ${ }^{\mathrm{a}}$ & 294 & 19.90 & 4.90 & 38.00 & 82.4 & 13.70 & 1885 & 6.60 \\
\hline Galeta $^{\mathrm{a}}$ & 143 & 10.90 & 4.00 & 32.50 & 74.0 & 12.80 & 1748 & 7.20 \\
\hline Payardi $^{\mathrm{a}}$ & 228 & 16.10 & 4.00 & 33.30 & 91.8 & 10.00 & 2094 & 7.50 \\
\hline \multicolumn{9}{|l|}{ Costa Rica } \\
\hline Punta Portete $^{a}$ & 268 & 14.70 & 8.40 & 34.50 & 102.0 & 22.60 & 3225 & 7.30 \\
\hline Punta Piuta $^{\mathrm{a}}$ & 525 & 11.40 & 9.80 & 25.60 & 99.0 & 19.80 & 6118 & 6.00 \\
\hline \multicolumn{9}{|l|}{ Colombia } \\
\hline $\begin{array}{l}\text { Cienaga Grande }{ }^{b} \\
\text { Australia }\end{array}$ & 623 & 91.00 & 23.30 & 12.60 & 32.5 & 13.20 & 15593 & 1.92 \\
\hline Port Jackson $^{\mathrm{c}}$ & - & 145.000 & 62.00 & 180.00 & - & - & - & - \\
\hline Port Jackson $^{\mathrm{c}}$ & - & 351.000 & 102.00 & 443.00 & - & - & - & - \\
\hline Hawksbury $^{\mathrm{c}}$ & - & 94.000 & 18.90 & 26.40 & - & - & - & - \\
\hline Port Hacking $^{\mathrm{c}}$ & - & 10.300 & 1.10 & 2.50 & - & - & - & - \\
\hline Queensland $^{\mathrm{d}}$ & 103 & $23-56$ & $1-12$ & 369.0 & $01-72$ & 1056.0 & 0.6 & - \\
\hline Brazil & & & & & & & & \\
\hline $\begin{array}{l}\text { Clean Mangrove } \\
\text { Hong Kong }\end{array}$ & - & 24.200 & 3.82 & - & - & - & 2464.0 & 0.60 \\
\hline Clean Mangrove $^{\mathrm{f}}$ & 96.00 & 43.000 & 2.60 & 31.20 & 2.90 & 1.20 & 1.08 & 0.320 \\
\hline Present study & 17.18 & 13.890 & 11.67 & 59.67 & 7.89 & 8.57 & 15.66 & 1.670 \\
\hline
\end{tabular}

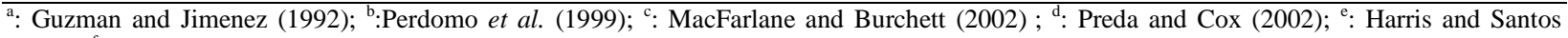
(2000); ${ }^{\text {f. }}$ Tam and Wong $(2000)$ 


\section{CONCLUSION}

In this study, correlation, factor and discriminant analysis were used for determining the environmental quality of road deposited sediments in terms of heavy metal accumulation and some soil properties. Correlation analysis shows a strong relationship between organic matter content on cadmium metal accumulation. Principal component analysis summarizes (reduces) the dataset into four major components representing the different sources of the elements. Using discriminant analysis, it was found that the metal concentrations are fairly well discriminated and correctly classified. This study generally concludes that the statistical methods can be a strong tool for monitoring of current environmental quality of road deposited sediments in terms of heavy metal accumulation and for predicating the future soil contamination.

\section{ACKNOWLEDGMENT}

The researcher acknowledges the head of department and laboratory staff of chemistry department, Federal University of Technology, Minna, Nigeria for all their support.

\section{REFERENCES}

Avila-Perez, P., M. Balcazar, G. Zarazua-Ortega, I. Barcelo-Quintal and C. Diaz-Delgado, 1999. Heavy metal distribution in bottom sediments of a Mexican reservoir. Sci. Environ., 234: 185-196. DOI: 10.1016/S0048-9697(99)00258-2

Awofolu, O.R., 2005. A survey of trace metals in vegetation, soil and lower animals along some selected major and roads in metropolitan city of Lagos. Environ. Monitor. Assess., 105: 431-447. DOI: 10.1007/s10661-005-4440-0

Baptista Neto, J.A., B.J. Smith and J.J. McAllister, 2000. Heavy metal concentrations in surface sediments in a nearshore environment, Jurujuba, sound Southeast Brazil. Environ. Pollut., 109: 1-9. DOI: 10.1016/S0269-7491(99)00233-X

Che, Y., Q. He and W.Q. Lin, 2003. The distributions of particulate heavy metals and its indication to the transfer of sediments in the Changiiang estuary and Hangzhou Bay, China. Mar. Pollut. Bull., 46: 123-131. DOI: $10.1016 / \mathrm{S} 0025-326 \mathrm{X}(02) 00355-7$

Damian, F. and G. Damian, 2007. Detoxification of heavy metal contaminated soils. Am. J. Environ. Sci., $\quad 3:$ 193-198. http://scipub.org/fulltext/ajes/ajes34193-198.pdf
De Miquel, E., J.F. Llamas, E. Chacon, T. Berg and S. Larsen et al., 1997. Origin and patterns of distribution of trace elements in street dusts: Unleaded petrol and urban lead. Atmosp. Environ., 31: 2733-2740. DOI: 10.1016/S1352-2310(97)00101-5

Ferguson, J.E. and N.D. Kim, 1991. Trace elements in street and house dusts: Sources and speciation. Sci. Total Environ., 100: 125-150. DOI: 10.1016/00489697(91)90376-P

Gorenc, S., R. Kostaschuk and Z. Chen, 2004. Spatial variations in heavy metals on tidal flats in the Yangtze Estuary, China. Environ. Geol., 45: 1101-1108. DOI: 10.1007/s00254-004-0968-5

Guzman, H.M. and C.E. Jimenez, 1992. Contamination of coral reefs by heavy metals along the Caribbean coast of Central America (Costa Rica and Panama). Marine Pollut. Bull., 24: 554-561. DOI: 10.1016/0025-326X(92)90708-E

Harris, R.R. and M.C.F. Santos, 2000. Heavy metal contamination and physiological variability in the Brazilian mangrove crabs, Ucides cordatus and Callinectes danoe (Crustacea: Decapoda). Mar. Biol., 137: 691-703. http://cat.inist.fr/?aModele $=$ afficheN\&cpsidt $=843313$

Huang, K.M. and S. Lin, 2003. Consequences and implication of heavy metal spatial variations in sediments of Keelung River drainage basin, Taiwan. Chemosphere, 53: 1113-1121. DOI: 10.1016/S0045-6535(03)00592-7

Jumbe, A.S. and N. Nandini, 2009. Heavy metals analysis and sediment quality values in urban lakes. Am. J. Environ. Sci., 5: 678-687. http://www.scipub.org/fulltext/ajes/ajes56678-687.pdf

Lakhan, V.C., K. Cabana and P.D. LaValle, 2003. Relationship between grain size and heavy metals in sediments from beaches along the coast of Guyana. J. Coast. Res., 19: 600-608. http://www.jstor.org/stable/4299201

Lin, Y.P., T.P. Teng and T.K. Chang, 2002. Multivariate analysis of soil heavy metal pollution and landscape pattern in Changhua County in Taiwan. Landscape Urban Plann., 62: 19-35. DOI: 10.1016/S0169-2046(02)00094-4

MacFarlane, G.R. and M.D. Burchett, 2002. Toxicity, growth and accumulation relationships of copper, lead and zinc in the Grey Mangrove Avicennia marina (Forsk.) Veirh. Mar. Environ. Res., 54: 65-84. DOI: 10.1016/S0141-1136(02)00095-8

Mahvi, A.H., D. Naghipour, V. Forugh and S. Nazmara, 2005. Teawaste as an adsorbent for heavy metal removal from industrial wastewaters. Am. J. Applied $\quad$ Sci., $\quad 2$ 2: 372-375. http://www.scipub.org/fulltext/ajas/ajas21372-375.pdf 
McAllister, J.J., B.J. Smith and J.A. Baptista Neto, 2000. The presence of calcium oxalate dihydrate (weddellite) in street dusts from Niteroi, Brazil and its health implications. Environ. Geochem. Health, 22: 195-210. DOI: 10.1023/A:1026593729453

McAllister, J.J., B.J. Smith, J.A. Baptista Neto and J.K. Simpson, 2005. Geochemical distribution and bioavailability of heavy metals and oxalate in street sediments from Rio de Janeiro, Brazil: A preliminary investigation. Environ. Geochem. Health, 27: 429-441. DOI: 10.1007/s10653-005-2672-0

Mielke, H.W., 1994. Lead in New Orleans soils: New images of an urban environment. Environ. Geochem. Health, 16: 123-128. DOI: 10.1007/BF01747908

Mihaly-Cozmuta, L., T. Visan, A. Mihaly-Cozmuta, C. Varga and V. Viman et al., 2005. Energetic aspects related to heavy metals adsorption on the surface of volcanic tuff $\mathrm{I}$. The influence of activation parameters in $\mathrm{Cu}^{2+}$ adsorption. Am. J. Environ. Sci., $\quad 1$ : 159-163. http://www.scipub.org/fulltext/ajes/ajes12159-163.pdf

Naqerotte, S.M. and J.P. Day, 1998. Lead concentrations and isotope ratios in street dust determined by electrothermal atomic absorption spectrometry and inductively coupled plasma mass spectrometry. Analysis, 123: 59-62. http://www.rsc.org/delivery/_ArticleLinking/DisplayAr ticleForFree.cfm?doi=a704940d\&JournalCode=AN

Odero, D.R., E. Semu and G.N. Kamau, 2000. Assessment of cottage industry-derived heavy metal pollution of soil within Ngara and Gikomba areas of Nairobi city, Kenya. Afr. J. Sci. Technol., 1: 52-62.

Ong, M.C. and B.Y. Kamaruzzaman, 2009. An assessment of metals $(\mathrm{Pb}$ and $\mathrm{Cu})$ contamination in bottom sediment from South China Sea Coastal waters, Malaysia. Am. J. Applied Sci., 6: 1418-1423. http://www.scipub.org/fulltext/ajas/ajas671418-1423.pdf

Pagotto, C., N. Remy, M. Legret and P. Le Cloirec, 2001. Heavy metal pollution of road dust and roadside soil near a major rural highway. Environ. Technol., 22: 307-319. PMID: 11346288

Perdomo, L., I. Ensminger, L.F. Espinos, C. Elsters and M. Wallner-Kersanach et al., 1999. The mangrove ecosystem of the Cienaga Grande de Santa Marta (Colombia): Observations on regeneration and trace metals in sediment. Mar. Pollut. Bull., 37: 393-403. DOI: 10.1016/S0025-326X(99)00075-2

Pereira, E., J.A. Baptista-Neto, B.J. Smith and J.J. Mcallister, 2007. The contribution of heavy metal pollution derived from highway runoff to Guanabara Bay sediments--Rio de Janeiro/Brazil. Ann. Braz. Acad. Sci., 79: 739-750. PMID: 18066440
Preda, M. and M.E. Cox, 2002. Trace metal occurrence and distribution in sediments and mangroves, Pumicestone region, southeast Queensland, Australia. Environ. Int., 28: 433-449. DOI: 10.1016/S0160-4120(02)00074-0

Rayment, G.E. and F.R. Higginson, 1992. Australian Laboratory Handbook of Soil and Water Chemical Methods. 1st Edn., Inkata Press, Port Melbourne, ISBN: 0909605688, pp: 330.

Sutherland, R.A. and C.A. Tolosa, 2000. Multi-element analysis of road-deposited sediment in an urban drainage basin, Honolulu, Hawaii. Environ. Pollut., 110: 483-495. DOI: $10.1016 /$ S02697491(99)00311-5

Sutherland, R.A., 2003. Lead in grain size fractions of road-deposited sediment. Environ. Pollut., 121: 229-237. DOI: 10.1016/S0269-7491(02)00219-1

Tahri, M., F. Benyaich, M. Bounakhla, E. Bilal and J.J. Gruffat et al., 2005. Multivariate analysis of heavy metal contents in soils, sediments and water in the region of Meknes (Central Morocco). Environ. Monitor. Assess., 102: 405-417. DOI: 10.1007/s10661-005-6572-7

Tam, N.F.Y. and W.S. Wong, 2000. Spatial variation of heavy metals in surface sediments of Hong Kong mangrove swamps. Environ. Pollut., 110: 195-205. DOI: 10.1016/S0269-7491(99)00310-3

Tiller, K.G., 1989. Heavy metals in soils and their environmental significance. Adv. Soil Sci., 9: 113-142.

Ujevic, I., N. Odzak and A. Baric, 2000. Trace metal accumulation in different grain size fractions of the sediments from a semi-enclosed bay heavily contaminated by urban and industrial wastewaters. Water Res., 34: 3055-3061. DOI: 10.1016/S00431354(99)00376-0

USEPA, 1996. Test Methods for Evaluating Solid Waste: Physical/Chemical Methods. 3rd Edn., USEPA, Washington, DC., pp: 40.

Watts, S.E.J. and B.J. Smith, 1994. The contribution of highway run-off to river sediments and implications for the impounding of urban estuaries: A case study of Belfast. Sci. Total Environ., 146: 507-514. DOI: 10.1016/0048-9697(94)90276-3

Zhang, W., L. Yu, S.M. Hutchinson, S. Xu and Z. Chen et al., 2001. China's Yangtze Estuary: 1. Geomorphic influence on heavy metal accumulation in intertidal sediments. Geomorphology, 41: 195-205. DOI: 10.1016/S0169-555X(01)00116-7

Zonta, R., L. Zaggia and E. Argese, 1994. Heavy metal and grain-size distribution in estuarine shallow water sediments of the Cona Marsh (Venice Lagoon, Italy). Sci. Total Environ., 151: 19-28. DOI: 10.1016/0048-9697(94)90482-0 